\title{
UNIVERSITYOF
}

FORWARD

THINKING

WESTMINSTER用

WestminsterResearch

http://www.westminster.ac.uk/westminsterresearch

Critical Environmental Law as Method in the Anthropocene

Philippopoulos-Mihalopoulos, Andreas

This draft chapter has been published by Edward Elgar Publishing in Research Methods in Environmental Law: A Handbook, edited by Andreas Philippopoulos-Mihalopoulos and Victoria Brooks, published in 2017.

http://www.e-elgar.co.uk/

The WestminsterResearch online digital archive at the University of Westminster aims to make the research output of the University available to a wider audience. Copyright and Moral Rights remain with the authors and/or copyright owners.

Whilst further distribution of specific materials from within this archive is forbidden, you may freely distribute the URL of WestminsterResearch: ((http://westminsterresearch.wmin.ac.uk/)).

In case of abuse or copyright appearing without permission e-mail repository@westminster.ac.uk 


\title{
Critical Environmental Law as Method in the Anthropocene
}

\section{Andreas Philippopoulos-Mihalopoulos}

Andreas Philippopoulos-Mihalopoulos, 'Critical Environmental Law as Method in the Anthropocene', in Andreas Philippopoulos-Mihalopoulos and Victoria Brooks (eds), Research Methods in Environmental Law: A Handbook, Elgar, 2017

\begin{abstract}
In an attempt to bring Critical Environmental Law to a discussion with the current planetary challenges such as the Anthropocene and climate change, and understand the methodological challenges that such a discussion ensues, I suggest three basic tenets from which environmental law can be examined: grammar, perspective and methodology. Grammar refers to the need for new concepts and ways of connecting the various bodies that participate and consist the environment. To this effect, I suggest some terms, such as continuum/rupture, human/nonhuman/inhuman, as well as geologic immersion and planetary withdrawal. Perspective refers to the way current thinking changes or at least is affected by the Anthropocene. Finally, methodology refers to the way critical environmental law must find ways to seek knowledge and the epistemological presuppositions of the limits of such knowledge. In conclusion, I offer four methodological demands of critical environmental law in order for the latter to adapt methodologically and integrate the Anthropocenic grammar and perspective.
\end{abstract}

\section{Introduction}

It is important to reconceptualise environmental law. We find ourselves at a geological, scientific and political juncture, respectively characterised by the Anthropocene, uncontainable climate change, and global crisis on various fronts. Rather than reducing itself to a reactive, ponderous and disciplinary-confined position, environmental law is ethically obliged to assume a much more active role in what is currently happening on the planet. I speak of environmental law as a whole and even 
as an agent on purpose: as I show here, environmental law is more than the sum of its human parts. Once we recognise this distinctly posthuman emergence, we can begin to lay down realistic strategies on how to act. As it stands, environmental law remains stranded in a modernist, humanist tradition, consistently failing to engage with the catenation of interdisciplinary and posthumanist structures that have emerged in the past few decades and literally changed the face of the planet. The allencompassing impact of the Anthropocene, at least as a discourse if nothing else, is enough to mobilise different, hitherto dormant, sides of environmental law.

In this chapter, I would like to build on my project of reconceptualising environmental law in the form of what I have called "critical environmental law". ${ }^{1}$ Briefly, critical environmental law's main impetus is to usher environmental law into a new space where traditional conceptualisations of disciplines, actors and jurisdictions are redetermined in the face of collapse of such steadfast distinctions as those between human and nonhuman, body and environment, subject and object, observation and participation, and epistemology and ontology. These distinctions have been under attack by several strands of theoretical developments across disciplines as I show below, and compel environmental law, if nothing else, at least to take position with regards to the discourses and determine their import. This has been vociferously brought home by the inauguration of the geological epoch of the Anthropocene, which is characterised by the planetary and indeed geologically-detectable impact of humans. $^{2}$

\footnotetext{
${ }^{1}$ A Philippopoulos-Mihalopoulos, 'Towards a Critical Environmental Law' in A PhilippopoulosMihalopoulos (ed.) Law and Ecology: New Environmental Foundations (London: Routledge, 2011) 18-38

2 P J Crutzen and E Stoermer, 'The Anthropocene' (2000) 41 IGBP Newsletter 17. See also the report of the Anthropocene Working Group of the $29^{\text {th }}$ of August, 2016, to the International Geological Congress, to be considered by the International Commission on Stratigraphy for their final decision, on
} 
With the Anthropocene, a new grammar is inaugurated, a different theoretical perspective is tried out, and an updated methodology ensues. The Anthropocene has managed to provide for all these new steps, influencing an unexpectedly large and broad variety of disciplines. Environmental law has not been left out of this wave, ${ }^{3}$ since, more than any other branch of law, it is directly involved in some of the fossilising and anthropogenic processes in the core of the Anthropocene. But so far, most attempts to deal with the challenges that come from such concepts as the Anthropocene or climate change from an environmental point of view have been partial, ${ }^{4}$ or even worse, espousing of the ubiquitous neoliberal 'green' economic agenda, entrusting the future of the planet to more technology, stronger ('but cleaner') industry, aggressive geoengineering, and other market-oriented mechanisms which sadly confirm Swyngedouw's characterisation of the Anthropocene as the 'opiate of the masses'. ${ }^{5}$

In order to reconceptualise environmental law along critical lines, I suggest that a return to the basics of the discipline of environmental law is needed. In an effort to deal with environmental law as both a discourse and a material agent, I will be introducing what I consider the three major environmental legal tenets: grammar,

how the Anthropocene is stratigraphically verifiable, making the Anthropocene an official geological epoch.

${ }^{3}$ See for example, C Gonzalez, 'Bridging the North-South Divide: International Environmental Law in the Anthropocene' (2015) 32 Pace Environmental Law (PELR) Review, 407; D Houston, 'Crisis Is Where We Live: Environmental Justice for the Anthropocene' (2013) Globalizations, 10, 3, 439; see also N Robinson, 'Fundamental Principles of Law for the Anthropocene?' (2014) Environmental Policy and Law, 44, 1-2, 13, whose work on principles for the Anthropocene is based on strong ethical considerations.

${ }^{4}$ Exceptions of course abound. See indicatively, A Grear, 'Deconstructing Anthropos: A Critical Legal Reflection on "Anthropocentric" Law and Anthropocene "Humanity"' (2015) Law and Critique, 26, 3, 225; S Adelman, 'Climate justice, loss and damage and compensation for small island developing states' (2016) Journal of Human Rights and the Environment, 7, 1, 32

${ }^{5}$ E Swyngedouw, 'The non-political politics of climate change' (2011) Acme 12, 1, 1. 
perspective and methodology. Briefly, I employ the term 'grammar' to explore the need for a new, anthropocenic and emphatically non-anthropocentric vocabulary that will deal with the challenges of the current global crisis. 'Perspective', on the other hand, refers to the way current thinking changes or at least is affected by the various planetary changes as already here and now - indeed, how current thinking is turning in order to accommodate the needs of the new epoch. Finally, 'methodology' refers to the new methods with which we must seek knowledge, as well as the epistemological presuppositions of the limits of such knowledge. I will examine the first two in the context of environmental law, and will offer some methodological suggestions in the form of critical environmental law.

The endeavour contains a few methodological challenges. The first challenge is the need for a radical interdisciplinarity, whatever the constraints of our respective disciplines. Methodologically, this requires an adequate knowledge of, and an openness to, at least those concepts and practices (such as the Anthropocene, posthumanism, new materialism, and so on) that trammel the various disciplines and push their boundaries from within. The second methodological challenge is to conduct research from a perspective that questions the traditional distinctions mentioned above, and notably that between human and nonhuman. This posits a particularly interesting issue for the researcher: namely, how to be both a human researcher and in sync with one's nonhuman extensions and mediations? And how to allow also the latter to form the way the research is generated? The third methodological challenge is how to work as committed environmental legal researchers, aiming at direct and immediate furthering of solutions with regards to the urgent planetary environmental problems we are facing; and simultaneously allow for creative, radical thinking that 
does not adhere to the rules of problem-solving but allows for an open space of theoretical and world-encompassing thinking. To paraphrase an old adage, the question is how to think both planetarily and locally at the same time.

\section{Critical Environmental Law's Grammar, or how to connect bodies}

Just as any branch of law, so is environmental law primarily thought of as a linguistic structure, working with texts of various levels and significance, whether international agreements, NGOs declarations, or local contracts. It is not disputed that these texts refer to bodies (human and nonhuman) and their relations across space and time. ${ }^{6}$ With few exceptions, ${ }^{7}$ however, this reference to bodies and objects is where considerations of materiality in law stop. The materiality of texts, and further the legal materiality beyond the textual and its import in the law, is regularly marginalised. This is a generalised issue of law's presumed linguistic primacy. While it is important for all strands of law to recognise how matter is implicated in legal decision-making, it is imperative for critical environmental law to embrace both its linguistic expression and its material manifestation. ${ }^{8}$ This is because of the fact that environmental law, more than other kinds of law, is deeply embedded in a materiality that brings together

\footnotetext{
${ }^{6} \mathrm{~N}$ Luhmann, Law as a Social System, trans. K Ziegert (Oxford, Oxford University Press, 2004).

${ }^{7}$ See for example, C Vismann, Files (Stanford, Stanford UP, 2008); E Grabham (2009) 'Shaking Mr Jones: Law and Touch', International Journal of Law in Context 5(4), 343353; B Latour, The Making of Law: An Ethnography of the Conseil D'Etat (Cambridge, Polity Press, 2009); A Pottage (2012) 'The Materiality of What?', Journal of Law and Society 39(1), 167-83.

8 I have attempted to bring these together in the concept of material metaphors in (2016) 'Flesh of the Law: Material Metaphors', Journal of Law and Society 43(1), 4565.
} 
humanity with the environment, while at the same time operating from within the linguistic domain. Just as words are needed to be placed in a certain grammatically correct way in order for sensible sentences to emerge, in the same way bodies need to be thought of in their spatiotemporal relations in order for critical environmental law to come up with the kind of radical propositions that are needed in the face of the current challenges. The challenge therefore, for us, critical environmental thinkers, is to bring forth the materiality of the law while working from within language, in order to construct a new critical environmental thinking.

There is, however, considerable resistance. In the opening pages of his book Ecological Thought, Timothy Morton writes: "one of the things that modern society has damaged, along with ecosystems and species and the global climate, is thinking."9 The kind of thinking Morton refers to, has been long forgotten in the name of problemsolving and solution-oriented practices. This does not mean that problem solving precludes every mode of thinking. On the contrary, it demands a thinking mode that is specific, unidirectional and targeted. By definition it needs to bracket issues that are not immediately relevant and assume a temporality that targets the present and the immediate future. This mode of thinking is applied in most environmental legal production processes. ${ }^{10}$ Issues such as the Anthropocene and climate change, however, opens up a different temporality and depth of thinking. It requires a focus that zooms out rather than in, observing humanity and its shenanigans from a distance. It requires a counter-intuitive pause and an opening up to include issues that were previously thought of as irrelevant, including planetary futures and inhuman

\footnotetext{
9 T Morton, Ecological Thought (Harvard University Press, 2010) 4.

${ }^{10}$ F Capra and U Mattei, The Ecology of Law: Toward a Legal System in Tune with Nature and Community (Berrett-Koehler, 2015).
} 
bodies, as I show below. It demands a supra-disciplinarity, some work on which must take place within the confines of every individual discipline (every discipline has the responsibility to start thinking of other disciplines) and also in unison as a collective emergence.

The challenge for environmental law is considerable. It must expand beyond the increasing epistemic closure that always demands a return to the law and its habitual mechanisms, and consider other disciplines in both their theoretical and applied manifestation. Indeed, the latter is the lesser of the two problems: in any environmental legal statute or court decision there is an inherent interdisciplinarity that needs to bring together epistemic advances from science, ecology, politics and economy, to name a few. But this interdisciplinarity is instrumentalised and as such, does not reach beyond the law and its needs. The various disciplines become translated into law for the demands of the particular problem, with its pre-determined, mostly short-term temporality. This remains the case despite some of the more visionary legal concepts, such as the principle of intergenerational equity that urges towards a slightly ampler but ultimately still limited temporality, especially when compared to Anthropocenic temporality, which is much broader. So, the basic epistemic challenge for environmental law is to adopt an interdisciplinary approach that escapes the narrow instrumentalism of decision-making, and extend this on a supra-disciplinary horizon of long-term futurity. 
Similarly to what has been called the grammars of climate change,$^{11}$ that refer to the questions of who speaks and how one speaks for pressing environmental issues, the need for a grammar of critical environmental law is pressing and invites the reemergence of a supra-disciplinary thinking by all involved, and of the kind in which Renaissance excelled. While a Renaissance breadth of knowledge would now be impossible due to the depth of specialised knowledge and the different understanding of stake-holders, an epistemic propensity towards supra-disciplinarity is the main grammatical invitation of the current epoch. In a way, this challenge is superior to the one augured by sustainable development - another mobilising concept that transcended disciplines, just as climate change and the Anthropocene have managed to do.

Let me, therefore, point to some of the new grammatical structures that will serve to connect bodies in a different way to the traditional environmental legal understanding of reference and move to a more embodied incorporation of materiality in the legal discourse. First, a reconfiguration of the connection between humanity and the rest of the planet demands a fine, somewhat paradoxical, balance. On the one hand, an understanding that, not only do humans depend on the planet (which is in the basis of many anthropocentric theories where nature is protected as resource); not even that nature is central to humanity (in the way ecocentrism and Earth jurisprudence has it ${ }^{12}$ ); but that there is such a continuity between them and the rest of the planet that any distinction is often arbitrary and on the basis of partial interests. On the other hand,

\footnotetext{
${ }^{11}$ C Barnett, P Cloke, N Clarke and A Malpass, Globalizing Responsibility: The Political Rationalities of Ethical Consumption (London, Blackwell, 2011).

12 What I suggest is different to ecocentrism in that, emphatically, here there is no centre yet there is difference. See my work on this in 'Actors or spectators? Vulnerability and critical environmental law', in A Grear and E Grant (eds), Thought, Law, Rights and Action in the Age of Environmental Crisis (Cheltenham, Edward Elgar, 2015).
} 
the Anthropocene and the anthropogenic climate change invite a return of anthropos as a new political and legal body that embraces the scientific developments of posthumanism, and yet asserts that humans are not the same as other material and immaterial bodies that populate the planet. ${ }^{13}$ The oft-rehearsed deep-ecology notions of oneness in terms of human and non-human bodies points to a need for an ecological flatness that does not offer any criteria of distinction, and therefore cannot differentiate between the various bodies. It is important, therefore, to retain difference and even perhaps human priority. As Kathryn Yussof puts it, "this priority is isomorphic and is not something that should be flattened out in relation to other life/minerals (as some argumentation in the posthumanities inadvertently does)." ${ }^{14}$ The other end of the spectrum is, however, a human exceptionalism, the kind of which we often witness and practice, whether consciously or unconsciously. This is especially the case in law, which is generally characterised by anthropocentric values. Paradoxically, this needs to be managed as an anthropocenic asset in terms of retaining human responsibility. Yussof again: "[i]t is a case of negotiating human exceptionalism rather than trying to do away with it all together, because that elision negates the power and responsibility that comes with what is inherited as a consequence of our humanism (the ontological debt)." ${ }^{15}$

To put it differently, we need to consider the connection between the indistinguishability between bodies on the one hand, and the de facto emergence of different bodies on the other. The indistinguishability between bodies refers to the way

\footnotetext{
13 A Grear, "Deconstructing Anthropos: A Critical Legal Reflection on "Anthropocentric" Law and Anthropocene "Humanity"' (2015) 26/3 Law and Critique 225-249.

${ }^{14} \mathrm{~K}$ Yussof, 'Geologic subjects: nonhuman origins, geomorphic aesthetics and the art of becoming inhuman' (2015) Cultural Geographies, 22, 3, 383, 399.

$15 \mathrm{ibid}$, at 399-400.
} 
bodies are always assembled in collectivities with other bodies, to the point that the limits of a (human but also any other) body become actually and epistemically fuzzy. Bodies, in other words, constitute a continuum. I have elsewhere defined the continuum as the surface that cuts across animate and inanimate objects, bodies, discourses and so on. ${ }^{16}$ This continuum is not equivalent to a flat ontology or the ecocentric unity of the world. ${ }^{17}$ It draws on Moira Gatens's description as "a plane of experimentation, a mapping of extensive relations and intensive capacities that are mobile and dynamic", ${ }^{18}$ in that it emphasises experimental and therefore unpredictable mobility of both material (extensive) and immaterial (intensive) bodies. It also draws on Jane Bennett's "ontological field without any unequivocal demarcations between human, animal, vegetable or mineral. All forces and flows (materialities) are or can become lively, affective, and signaling ... portions congeal into bodies, but not in a way that makes any one type the privileged site of agency."19 Indeed, the continuum I am suggesting here is acentral and multi-agentic, constituted of affective excess and of bodies melting into each other's contours. It is also a tilted, power-structured surface, on which bodies move, rest and position themselves, affecting the tilt while being affected by it. Stronger bodies affect the continuum in radical ways, making it tilt according to their positions: the global North is stronger than the South; a corporation is often stronger than a singe individual; a collective is sometimes stronger than a developer; a tsunami is nearly always stronger than the holiday-makers, and global warming is stronger than all of us.

\footnotetext{
${ }^{16}$ A Philippopoulos-Mihalopoulos, Spatial Justice: Lawscape Body Atmosphere (London, Routledge, 2015).

17 Or the Deleuzian/Guattarian plane of immanence, namely "the 'holding together' of heterogeneous elements: G Deleuze and F Guattari, A Thousand Plateaus: Capitalism and Schizophrenia, trans. B Massumi (London, Athlone Press, 1988) 323; G Deleuze and F Guattari, What is Philosophy?, trans. H Tomlinson and G Burchell (New York, Columbia University Press, 1994) 141.

${ }^{18}$ M Gatens, 'Through a Spinozist Lens: Ethology, Difference, Power', in P Patton (ed.), Deleuze: A Critical Reader (Oxford, Blackwell, 1996) 165.

19 J Bennett, Vibrant Matter: A Political Ecology of Things (Durham, Duke University Press, 2010) 117.
} 
The concept of indistinguishability refers to the commonality of all bodies as 'inhabitants' of the continuum. But so far, the anthropocentric continuum reserved a special place for the human, indeed for Man. Think of the idea of 'man' as propagated in Enlightenment: a white male of ideal corporeal proportions, gifted with reason, common sense, knowledge, potential, ready to conquer the world. ${ }^{20}$ But we know now, after the extensive discussion on the posthuman, that the human has never been what we thought. The human is always mediated (by its body, by the space around it and by the space that the human body generates, by other bodies, whether human, natural, artificial, and so on). This is intimately connected to the fact that a body cannot be a neatly defined entity. The body does not have an outline. If they were a painting, bodies would be Venetian dashes of colour without drawn linear boundaries, staging through their expansive leaking a radical withdrawal from the Florentine canon of humanist containment. Deleuze writes: "the edge of the forest is a limit. Does this mean that the forest is defined by its outline?...We can't even specify the precise moment at which there is no more forest."21 All bodies are leaking. By 'all bodies' I mean human and nonhuman. While in traditional environmental thinking, whenever included, nonhuman bodies have been either resource, context or the negative of the dialectics of humanity, here I follow the schools of thought largely identified as new materialisms, non-representational theory, speculative realism and object-oriented ontologies, ${ }^{22}$ themselves generally drawing from a Spinozan/Deleuzian understanding of the body. Thus, for Deleuze, "a body can be anything: it can be an animal, a body

\footnotetext{
${ }^{20}$ See A Grear, 'Challenging corporate 'humanity': legal disembodiment, embodiment and human rights' (2007) Human Rights Law Review 7, 3, 511.

${ }^{21}$ G Deleuze, Cours Vincennes: Sur Spinoza, 17.02.1981 in L Lambert, The Funambulist Pamphlets 01: Spinoza (New York, Punctum Books, 2013) 74.

${ }^{22}$ See for example D Coole and S Frost, New Materialisms: Ontology, Agency and Politics (Durham, Duke University Press, 2010); Bennett, supra n. 19; Thrift, 2007.
} 
of sounds, a mind or idea; it can be a linguistic corpus, a social body, a collectivity."23 All bodies are assemblages, namely aggregations of human and nonhuman bodies that are contingent upon the conditions of their emergence and which do not presuppose the centrality, and certainly not the exclusive presence, of the human. What is more, assemblages are both actual, namely space and matter, and virtual, namely potential, but still real. Actual and virtual are not found in a dialectical opposition; nor does the actual determine the virtual. ${ }^{24}$ Rather, there is no ontological distinction between the two, and if anything, the actual is determined through its folding with the virtual. In this sense, current weakness or at least lack of strength is always affected by the virtual potential of its evolution into a much stronger body. Post-colonial environmental legal studies amply show both how the various positions of the bodies (North/South, urban poor versus urban elite, and so on) are artificially maintained in positions of subjugation due to capitalist interests; and how these positions can and do change, usually according to a neoliberal economic machine that encourages growth at the expense of environmental protection. ${ }^{25}$

So, if all bodies are assemblages and if no body has a definitive contour, how do bodies differentiate themselves from each other? How do singularities emerge from the continuum? And how is a researcher to carve out their own bodies of study and analyse them? These singularities emerge through ruptures. Ruptures interrupt the continuum, cutting the links between bodies and allowing

${ }^{23}$ G Deleuze, Spinoza: Practical Philosophy, trans. R Hurley (San Francisco, City Light Books, 1988) 127.

${ }^{24}$ G Deleuze, Cinema 1: The Movement-Image (London, Athlone Press, 1986).

25 See C Gonzalez, 'Bridging the North-South Divide: International Environmental Law in the Anthropocene' (2015) 32 Pace Environmental Law (PELR) Review, 407; S Humphreys and Y Otomo, 'Theorising International Environmental Law' in F Hoffmann and A Orford (eds) The Oxford Handbook of International Legal Theory (Oxford, Oxford UP, 2014). 
differences/individualities/subjectivities and eventually singularities to emerge. In thinking of the continuum, I have been inevitably influenced by Foucaultian biopolitics because its sovereignty is diffused and embodied in each participating body. It differs from the biopolitical, however, because it is characterised by the persistent erection of boundaries in the form of ruptures without predetermined ethical value. Ruptures can be both positive differences that encourage identity, as well as exclusions or hierarchies that discourage specific kinds of identity; they can be conflicts (necessary or engineered) as well as Deleuzian folds, namely co-emerging assemblages, and therefore ontological differentiations and 'gatherings'; they can also be epistemological necessities: we need to differentiate, according to the foundational fantasy of distinction between self and environment, as Teresa Brennan writes. ${ }^{26}$ They can also be arbitrary methodological dissections that separate the body on which the research will focus, from the body that will necessarily be excluded. Whatever they are, ruptures remain part of the continuum. Rather than annulling it, ruptures nourish the continuum, which can be thought of as a (continuous) series of ruptures. I have employed the term continuum in different contexts, but it is consistently characterised by this one quality: it is always ruptured, indeed self-ruptured, through foldings and distinctions on its surface. Sometimes illusionary necessities and other times ontological facts, ruptures are the locus of singularity in the continuum. Ruptures constitute the continuum, to the point that one is left only with a continuity of ruptures. This is the ultimate exposure of the necessary arbitrariness of disciplinary research: the researcher must always be conscious of the fact that, however clear-cut some epistemological ruptures might seem, one always remains entangled in assemblages, and any separation is temporally and spatially conditioned.

${ }^{26}$ T Brennan, The Transmission of Affect (Ithaca and London, Cornell University Press, 2004). 
Through ruptures, bodies differentiate themselves from other bodies. According to Spinoza, bodies differentiate themselves on the basis of their differentiated velocities or pauses - it is all about how a body moves or rests. A human body will be faster than a chair will be faster than the plant will be faster than the fossil, and all of them will be slower than a typhoon. Rupture enables a difference in movement that results in a repeated difference. Yet, precisely because the continuum is a series of ruptures, ruptures do not rupture the continuum as such: they are all inscribed within. So, the continuum is crossed by lines that produce meaning, while continuously being ruptured by them. Lisa Blackman in her seminal work on the body, ${ }^{27}$ has called this the problem of 'the one and the many', namely the ontological difficulty of being coherent yet multiple, in other words, self yet othering. Karen Barad has introduced the term "agential separability" to signal the need for boundaries between bodies. ${ }^{28}$ These boundaries are not placed as fixed constructions between subject and object, human and non-human, or indeed animate and inanimate. Rather, they emerge in order to produce meaning relative to the continuum on which the boundary appears. I understand this as a rupture that brings agency forth without flattening it to an allconnected ontology. It is significant that these boundaries are not conceptualised as either prior or immutable: they are drawn every time as part of the emergence of differentiated bodies - namely, the emergence of agency. The main challenge is how to avoid categorising either continuum or rupture as inferior, namely how to escape the trap of mapping them "onto differentiations made between the civilized and the primitive, the superior and the inferior, the simple and the complex, and the impulsive

\footnotetext{
${ }^{27}$ L Blackman, Immaterial Bodies (London, Sage, 2012).

${ }^{28} \mathrm{~K}$ Barad, Meeting the Universe Halfway: Quantum Physics and the Entanglement of Matter and Meaning (Durham, Duke University Press, 2006) 175.
} 
and the environmental." 29 Indeed, how not to make rupture and continuum a dialectic of opposites, namely a question of positive presence and negative absence, but a folding co-emergence.

This is also the challenge for critical environmental law: to put it more concretely, how to manage the fact that humans are everywhere, affecting the geology and future history of the Earth even after our extinction, while at the same time being embedded in a continuum of indistinguishability. As the editors of New Materialisms Diana Coole and Samantha Frost write, we have moved away from an epoch where

agents are exclusively humans who possess the cognitive abilities, intentionality, and freedom to make autonomous decisions and the corollary presumption that humans have the right or ability to master nature. Instead, the human species is being relocated within a natural environment whose material forces themselves manifest certain agentic capacities and in which the domain of unintended or unanticipated effects is considerably broadened. ${ }^{30}$

For environmental law, this means that the boundary between a body and its environment can no longer be taken as a given. The main find of the Anthropocene is that our presence on the Earth necessarily includes our "environment", whether "natural" or otherwise. We are always in an assemblage with the planet. A body is an assemblage of various conditions and materialities. Eben Kirksey's multispecies families $^{31}$ is an example of such an assemblage containing human and animal bodies,

\footnotetext{
${ }^{29}$ Blackman, supra n. 27, at 59.

30 Coole and Frost, supra, n. 22, at 10.

${ }^{31}$ E Kirksey, 'Multispecies Families, Capitalism, and the Law' in I Braverman (ed.), Lively Legalities (London, Routledge, 2016); see also J Lorrimer, 'Multinatural geographies for the Anthropocene' (2012) Progress in Human Geography, 36, 5, 59.
} 
discursive bodies of economics, politics and law, conservation agencies, wildlife experts, government agents and hobbyists, specific spatialities, affects from gentleness to aggression, and so on. The total sum of these connections constitutes a body that is internally ruptured in an infinity of modalities. ${ }^{32}$

Critical environmental law, therefore, invites us to think of a fractured grammar of continuum and ruptures, of ruptured continuum and continuous ruptures. These are heuristic tools, indeed a vocabulary or at least a mode of thinking that allows disciplines such as environmental law to remain intimately connected to everything else by engaging with the indistinguishability of bodies, and also accept the need for differentiation and draw it in a velocity and mode that serves its purpose. This enables the law to question the unchallenged perpetuation of such existing accepted assemblages as environment and economy, or sustainability and growth, and start experimenting with different assemblages that include the non-human in its ruptured polyvalence.

\section{Critical Environmental Law's Perspective, or how to be in and out at the same} time

Claire Colebrook writes: "the anthropocene thought experiment also alters the modality of geological reading, not just to refer to the past as it is for us, but also to

32 T Morton, Hyperobjects: Philosophy and Ecology after the End of the World (Minneapolis, University of Minnesota Press, 2013). 
our present as it will be without us. We imagine a viewing or reading in the absence of viewers or readers, and we do this through images in the present that extinguish the dominance of the present." 33 The perspective is changing radically. The Anthropocene demands from environmental law an epistemological distance from the object of study, both spatially and temporally. In order to observe the effects of the human onto the Earth and ways in which we can mitigate them, we must withdraw: spatially to get an understanding of the way the crust of the Earth is altering due to our presence; temporally and into the future of a human extinction, "in the absence of viewers or readers", where the planet returns to its slowness after that brief human interval; and epistemologically, withdraw from law in order to delve back into it later on, but only after we will have immersed ourselves in geology, science, anthropology, geography, ethics.

These notions perhaps seem too large for environmental law. They open up existential gushes that have little to do with the day-to-day operations of, say, the laws on pollution. As Upendra Baxi writes, "the question of urgency of global social policy is often considered vast enough to permit the luxury of ethical deliberation." ${ }^{34}$ But if the current planetary challenges are to be heeded, this has to change. An environmental law open to the ruptured continuum must adopt a different, more ethically situated perspective to the one traditionally understood. The perspective I am suggesting here is the fold between, on the one hand, a withdrawal of the law from the object in hand, in order for a planetary jurisprudence to emerge; and, on the other, an immersion to the geological strata of law with an aim of understanding a mineralised jurisprudence.

\footnotetext{
${ }^{33}$ C Colebrook, Death of the PostHuman: Essays on Extinction, Vol. 1 (Ann Arbor, Open Humanities Press, 2014) 30.

34 U Baxi, 'Towards a climate change justice theory?' (2016) 7 Journal of Human Rights and the Environment, 7, 10.
} 
I employ withdrawal here as a tool of resistance against an atmosphere of absolute inclusion in what Timothy Morton has named hyperobjects: objects characterised by viscosity, nonlocality, temporally undulating and constantly phasing. Morton's prime example of a hyperobject is global warming. As a hyperobject, global warming is characterised by an absence of distance between the implicated bodies: raindrops on our face is global warming, just as the act of flushing away our toilet waste thinking that it ends somewhere away. Its viscous nature means that there is no distance between here and away. Everything is within, assembling into the continuous space of the hyperobject yet at the same time withdrawing from it: global warming is not here either. "The octopus of the hyperobject emits a cloud of ink as it withdraws from access. Yet this cloud of ink is a cloud of effects and affects." ${ }^{35}$ The affects and effects left behind are not causal, at least not in the sense of being merely the sign of the cause. Rather, they all constitute the hyperobject; but they are often cut into palatable pieces of locality and present: they all become little ruptures placed at a distance in order to be apprehended. "It's never the case that those raindrops only fall on my head! They are always a manifestation of global warming!"36 These ruptures are also part of the object, "are simply the invisible presence of the hyperobject itself, which looms around us constantly." ${ }^{37}$ In their phasing, objects appear only partially, as indexical signs of their spatiotemporal distribution, and never in their entirety. Indeed, what is there to appear in global warming, if not the entire Earth, fractal and multiscalar, apprehended by different systems, such as politics, media, science, economics, ecology, and so on, all putting between themselves and the hyperobject a

\footnotetext{
${ }^{35}$ Morton, supra, n. 32, at 39.

36 ibid, at 48.

$37 \mathrm{lbid}$, at 7 .
} 
desperately constructed distance of observation? How can it present itself, and to whom, if everyone is implicated in this hyperobjective implicate order of global warming? We are all in it, complicitly constituting its continuum.

The total inclusiveness of the hyperobject (which is not of course just climate change but also the Earth's environmental degradation as a whole) is an aspect of the continuum which environmental law needs to resemiologise, and from which to withdraw. The operations of the hyperobject need to be conceived as a whole in an integrated, planetary manner, however strong the gravitation attraction of the hyperobject might be especially in its local manifestations (think of state-based pollution measures). The Anthropocene offers just this possibility of withdrawal. Clare Colebrook writes: "the positing of the anthropocene era relies on looking at our own world and imagining it as it will be when it has become the past...We can see, now, from changes in the earth's composition that there will be a discernible strata that-in a manner akin to our dating of the earth's already layered geological epochs—will be readable." 38 The withdrawal is both spatial and temporal, planet-embracing and futuretending.

Environmental law needs to see the whole hyperobject (or at least attempt a construction) as a planetary problem, and elevate the planet on an agentic level. Only subsequently can environmental law define its own role accordingly. As Rory Rowan writes, "whereas 'the global' suggests a relatively flat, anthropocentric conception of the Earth focused on the construction of social relations on the surface, 'the planetary', by contrast, points to a more complex, volumic, stratified understanding of an Earth

${ }^{38}$ Colebrook, supra, n. 33, at 26. 
constituted through dynamic geo-social entanglements. Accordingly, the Anthropocene creates opportunities to cast the planet itself as a key player in the drama of human politics rather than simply its stage." 39 The role of environmental law in this is pivotal, as long as it starts thinking in terms of the planet rather than in the old geopolitical terms of globality (this does not only apply to international environmental law but also very much to regional and national manifestations). Such a shift would come about with a withdrawal from given legal mechanisms such as the standard balance of interests and narrowly definitions of interest, harm and causal proof. Environmental law must perform a withdrawal from the very inclusivity of this hyperobject: if it carries on operating within it, environmental law falls victim to the devastating rhetoric of piecemeal action and generally accepted impossibility of actually doing anything radical enough that will halt environmental decline. In a way, environmental law needs to stop being so thoroughly law and begin becoming more environmental: to withdraw from itself and its own habitual legal mechanisms and to move to a different plane from where the issue of environmental degradation will appear as a whole, in its all-ingesting hyperobject presence. From there on, preventive action must be given priority over economic interests and lack of scientific proof, in accordance to a more idealised (but critically realistic, in view of the conditions) understanding of the precautionary principle; issues of intergenerational equity on a planetary scale that includes the future of human extinction must tangibly affect every legal decision and in course change the core of environmental law, from a generally rather conservative, piecemeal and overtly technical legal branch to the visionary, open and given to futurity way of legal thinking and acting that it could be.

\footnotetext{
${ }^{39}$ R Rowan, 'Notes on politics after the Anthropocene' (2014) in E Johnson et al. (eds) Special Issue 'After the Anthropocene: Politics and geographic inquiry for a new epoch' Progress in Human Geography, 38, 3, 439, 448
} 
On the other side of withdrawal lies immersion. It begins with the fact, suggested by Timothy Morton, ${ }^{40}$ that we are witnessing the end of the biologically-determined human subject and the inauguration of a distributed humanity operating as a geological agent. Humanity and its activities can no longer be understood as mere thought advances, or even corporeally embedded presences, but significantly as mineralised temporalities. Kathryn Yussof puts it clearly: "[t]he Anthropocene can be seen as a remineralization that is prompting reflection of the future fossilization of humanity... This is largely a result of being able to 'take up' a bloated payload of geologic force, courtesy of fossil fuels. In this sense the Anthropocene represents a moment of acknowledgement of a geologic social body politic, but in which our discourses for the critique of power (i.e. biopolitics) are configured to a version of 'life' that does not take account of this geology." ${ }^{\text {11 }}$ The Anthropocene presents us with a depth (of subjectivity, politics, law) that has so far been excluded, and in which we need to immerse ourselves: the geological depth and its effect on existing discussions on biopolitical control. What will happen to the law if it considers the mineralisation of the body? The law will be required to immerse itself deeper in the geology of the Anthropocene and, once again, reconsider its basic notions. Think, for example, of the understanding of private property as a fundamental human right. In the light of anthropocenic mineralisation, property becomes a planetary loan that has relied on the overexploitation (a "bloated payload") of fossil fuels. Property becomes less secure, less exclusionary, much more permeable. It needs to accommodate the logic of geologic circularity, namely the eventual fossilisation of humanity, and indeed the

\footnotetext{
40 Morton, supra, n. 9

${ }^{41}$ K Yussof, 'Anthropogenesis: Origins and Endings in the Anthropocene' (2016) Theory, Culture \& Society, 33, 2, 5.
} 
vanity of it all. It moves increasingly towards a much more expanded understanding of commons.

Immersion entails an acknowledgement of chthuloid (namely, of the deep Earth) verticality and a serious engagement with the ethical consequences of such an acknowledgement. This is what Donna Haraway has called the Chthulucene, namely an epoch which gives priority to the constant assemblaging of human with other nonhuman materialities. ${ }^{42}$ Haraway prefers this to the Anthropocene because it describes more accurately the constant implication of the human with other Earthly entities rather than artificially detaching the human from the assemblage. As Kathryn Yussof puts it, "considering the human within geologic time poses the problem of thinking an inhuman milieu, both before, after and internal to "us."'43 The inhuman, namely the geological, becomes part of the human and expands it from within. What is more, the Anthropocene demands a geophilosophical situatedness of thought in relation to the Earth. Reza Negarestani writes: "geophilosophy is a philosophy that grasps thought in relation to earth and territory...it is a philosophy that, perhaps unconsciously, grasps thought in relation to two traumas, one precipitated by the accretion of the earth and the other ensued by the determination of the territory. Whilst the former trauma lies in the consolidation of the earth as a planetary ark for terrestrial life against the cosmic backdrop, the latter is brought about by a combined geographic and demographic determination of a territory against the exteriority of the terrestrial plane and fluxes of populations of all kinds." 44 These two traumas, distinctly

\footnotetext{
${ }^{42}$ See 'Anthropocene, Capitalocene, Chthulucene: Staying with the Trouble', a lecture given by Donna Haraway at University of California, Santa Cruz on $5^{\text {th }}$ September 2014, available at https://vimeo.com/97663518.

${ }^{43}$ Yussof, supra, n. 14, at 388 .

${ }^{44} \mathrm{R}$ Negarestani, "Triebkrieg", unpublished manuscript, 5, cited in B Woodard, On an Ungrounded Earth: Towards a New Geophilosophy (Punctum Books, 2013) 14.
} 
anthropocentric and a direct effect of the Anthropocene, are also specifically legal. They both require an intervention that guarantees limits, while at the same time allocating responsibility. This is an anthropocentric legality that chops up the surface of the Earth in territorial modes that include other populations as resources (rather than allowing for multiple territories in terms of animal populations); and then delegates the whole Earth to the status of resource ('ark') for the human future. A geophilosophical position attempts to mend these traumas through the only way possible. Colebrook writes: "the anthropocene thought experiment also alters the modality of geological reading, not just to refer to the past as it is for us, but also to our present as it will be without us. We imagine a viewing or reading in the absence of viewers or readers, and we do this through images in the present that extinguish the dominance of the present." 45

Rethinking the basics would also include the differential position of both in and out: not all can be equal in terms of their responsibility towards the overexploitation of resources. As Chakrabarty writes, ${ }^{46}$ the Anthropocene risks becoming another totalising imposition (a hyperobject?) flattening historical and geographical injustices and presenting a total, unified humanity in terms of the share of systematic destruction of nature. In other words, "how humanity is deployed as a method of erasure that obfuscates climate racism, social injustice in fossil fuels, and differentiated histories of responsibilities through homogenization in a 'we' of the Anthropocene." 47 The tilt in the continuum disrupts the happy flatness of some of the Anthropocenic rhetoric. We are not one humanity facing its responsibility before the Anthropocene. Rather, we are a

\footnotetext{
45 Colebrook supra, n. 33, at 30.

46 D Chakrabarty, 'The Climate of history: Four theses' (2009) 35 Critical Inquiry, 197.

47 Yussof, supra, n. 41, at 6-7.
} 
continuum of ruptured shares, some more, some less (no one however with no share in the responsibility).

The continuum changes: rather than flat, like much of current ontologies, new materialisms and some ecological thinking seem to suggest, it is now revealed to be manifold, full of fissures and deep ruptures, heavily politicised by historical and geographical processes. Critical environmental law is to cultivate "a depth relation that is something like a charge in its fathoming of deep, underground spaces."48 Inhuman (geology) and non-human (biology) constitute the assemblage of what the human is in the epoch of the Anthropocene. In other words, the methodological responsibility of the researcher is one of both withdrawal and immersion: withdraw from the present in order to read it as nonhuman future; withdraw from centrality while retaining omnipresence; withdraw from the given legal mechanisms in order to withdraw from the hyperobject. But also, immerse ourselves in the geophilosophical understanding of the human; immerse the law in a mineralisation that extends into a deep future; and immerse into the differentiated responsibility that humanity has in the face of anthropocenic environmental degradation.

\section{Critical Environmental Law's Methodology, or how to get to grips with law's materiality}

${ }^{48}$ Yussof, supra, n. 14, at 401. 
There is no question that the Anthropocene affects the way environmental legal research and thinking in general should take place. But the Anthropocene is not an isolated move. If it were, it would not have captured the collective imagination the way it has. It is one more stage in the recent evolution towards a more embedded, material thinking about the human and the world at large. What has started with Catherine Merchant's Death of Nature ${ }^{49}$ and carried on with Deep Ecology and post-ecologism, ${ }^{50}$ has now found an outlet in arguably more supra-disciplinary ventures such as the spatial turn, the corporeal turn, the affective turn, and such philosophical currents of thought as posthumanism, new ontologies, new materialism and speculative realism. The Anthropocene is an addition to this long yet compact thinking evolution, and brings the need for an expansive thinking and acting, a differential understanding of space and time in terms of depth, a need for strategic withdrawal for hyper-inclusion, and a reconfiguration of human exceptionalism.

In what follows, I would like to offer four methodological steps of Critical Environmental Law in order to show how they are affected by the planetary challenges we are facing. This is not a programmatic description of how things should be solved, but suggestions for a methodology of environmental law, which demands a conceptualisation of environmental law that moves beyond the usual distinctions between anthropocentrism and ecocentrism; unproblematised distinctions between environment and human; and standard methodologies of legal access to knowledge.

\subsection{An Ontologised Environmental Law}

\footnotetext{
${ }^{49} \mathrm{C}$ Merchant, The Death of Nature: Women, Ecology and the Scientific Revolution (Wildwood House 1980).

50 I Blühdorn, Post-ecologist Politics (London, Routledge, 2000).
} 
"With the arrival of the Anthropocene, this division [between human/nonhuman or nature/culture] is de-ontologized; as such, the separation appears instead as an epistemological product mistakenly presumed as a given fact of being."51 The Anthropocene brings to the fore an ontology of continuous connection between bodies. In so doing, it instructs us to question the well-trodden paths of epistemology, and begin placing them in a wider context. Why is it that human rationality needed this rupture between human/nonhuman? Why this need to naturalise what should have remained transparent epistemological distinctions, arguably necessary to understand the world, but ultimately misleading and obscuring of the ontology of the continuum? Continuing in this vein, one would be forced to question that major distinction between epistemology and ontology: ${ }^{52}$ can we afford to carry on allowing Eurocentric, Capitalocenic, ${ }^{53}$ neoliberal, market-originating epistemological tools to determine what we take as ontological truths? Can such a distinction seriously be maintained in view of the fact that the Anthropocene also augurs the de-individualisation of the human in favour of a human collectivisation as a geological agent that affects the Earth, ${ }^{54}$ and further a human fossilisation as a return to the Earth as the a priori agent? This ontological take affects critical environmental legal method in two main ways: first, it demands a collapse of the distinction of a mechanistic, slow, procedure-led environmental law on the one hand, and an urgent tool of rapid dealing of environmental degradation on the other, that would deal with the issues as a priority and on a planetary level where resources are not about economic capabilities of

\footnotetext{
${ }^{51}$ E Turpin, 'Who Does the Earth Think It Is, Now?', in E Turpin (ed), Architecture in the Anthropocene: Encounters Among Design, Deep Time, Science and Philosophy (Open Humanities Press, 2013) 8.

${ }^{52}$ See R Brasier, 'Concepts and Objects' in L Bryant, N Srnicek and G Harman (eds) The Speculative Turn: Continental Materialism and Realism (re.press, 2011).

53 supra, n. 42.

${ }^{54}$ Morton, supra, n. 9.
} 
access but about geological finitudes. The method of accessing knowledge (epistemology) is responsible for the construction of such knowledge - thus, if environmental law follows a method of slow legal deliberation, it also generates a reality filled with unresolvable problems. Second, the ontological practice of the Anthropocene demands the collapse of traditional disciplinary boundaries, further fossilised by research councils, discipline-specific assessment exercises, and sclerotic university structures that operate along obsolete disciplinary distinctions. Critical environmental law is to be seen as a tool of resistance against fixed institutional structures that drown rather than encourage relevant research.

\subsection{A Material Environmental Law}

Critical environmental law can no longer hide behind the usual legal logocentric panoply that insulates environmental law from materiality. We now know that, as Austin Sarat writes, "the law is all over": ${ }^{55}$ this is a call to claim law's spatial, corporeal, emotional, sensory presence that has been subsumed to the critique of discourse. More than other legal disciplines, environmental law is exposed to its own materiality: dealings with scientific thresholds, ecological catastrophes, urban poverty, sick bodies and polluted atmospheres. Above all, the Anthropocene shows that environmental law is already itself a body, ${ }^{56}$ namely an assemblage of various materialities, spaces and disciplines. As a body, environmental law is both singular and part of the continuum:

\footnotetext{
55 A Sarat, “ "...The Law is All Over”: Power, Resistance and the Legal Consciousness of the Welfare Poor' (1990) Yale Journal of Law and Humanities, 2, 2, 343.

56 This is why, as D Houston (2013) 'Crisis Is Where We Live: Environmental Justice for the Anthropocene', Globalizations, 10, 3, 439, points out, we must not forget the existing environmental narratives of environmental activism but built on their successes and carry on with local action.
} 
it affects and is affected by other bodies. Environmental law must be thought critically, as a multi-layered, planetary, fragmented discipline, characterised by horizontalities that follow the transboundary nature of pollution, and verticalities that reach deep into the planet's space and time. There is no more room for such antiquated debates as anthropocentrism versus ecocentrism. ${ }^{57}$ The Anthropocene has exposed the grand paradox of the absence of centre. To be a singularity amidst a plane of other singularities entails a radical acentricity, which is much more than a call for the inclusion of uncertainty in environmental law. Rather, it is an invitation to a praxisoriented, spatially specific, material approach that considers every problem in its singularity.

\subsection{A Mineralised Environmental Law}

Environmental legal agency in the era of Critical Environmental Law cannot be limited to humans. The earlier posthuman understanding of the human as an assemblage is enough to cloud the agentic certainty. The Anthropocenic mineralisation of thought introduces an agentic tripartite: human (as assemblage, without contours), nonhuman (assemblages where the biological - animals and plants - but not the human prevails), inhuman (assemblages where the mineral prevails). Any carving of agency from the continuum requires a rupture, often artificial and arbitrary. ${ }^{58}$ Critical environmental law, however, must move towards a closer reading of the Anthropocenic geological circularity (life has always originated in and will always return to minerals) and consider

\footnotetext{
${ }^{57}$ See my take on this in 'Epistemologies of Doubt', in A Grear and L Kotzé (eds), Research Handbook On Human Rights And The Environment (Cheltenham, Edward Elgar, 2015).

${ }^{58}$ For agentic emergence in law, see A Philippopoulos-Mihalopoulos, 'Lively Agency: Life and Law in the Anthropocene', in I Braverman, Lively Legalities (London, Routledge, 2016).
} 
issues such as the recognition of legal agency of bodies such as mineral formations (e.g., fossil fuels) and even the planet as a whole. ${ }^{59}$ The methodological challenge of this is as grand as the responsibility of the critical researcher: it demands a much longer temporal horizon, in comparison to which even intergenerational equity might appear narrow, short-sighted, anthropocentric and solution-oriented. Instead, a planetary, agenerational equity is needed, that emerges in every single (human, nonhuman, inhuman) body while at the same time exceeding the bodies of its emergence and reaching for the whole planet.

\subsection{A Situated Environmental Law}

Human exceptionalism must be managed in order to create the conditions for assuming responsibility, regardless of proof of causal link. There is no doubt that humans are only one participant in the environmental decline; yet, as the Anthropocene has taught us, they are always a participant, always situated within the ecological conditions of our planet. Strict liability for historical anthropocenic environmental degradation is consonant with assemblage-thinking, where all bodies are complicit with the degradation. However, the responsibility is not flat. Depending on where each body is situated in the assemblage, the responsibility changes. This is not about proof but about historical presence. It is clear that responsibility now becomes situational: it is the juridical responsibility of situating one's body within an assemblage. Responsibility needs to be thought of as extended, namely both material

\footnotetext{
${ }^{59}$ Especially the latter is connected to what A Neimanis, C Åsberg and J Hedréncall, 'Four Problems, Four Directions For Environmental Humanities: Toward Critical Posthumanities For the Anthropocene', (2015) Ethics \& Environment 20, 1, 67, call the problem of compartmentalization of environmental questions.
} 
and unrestricted by the immediate or the local. Doreen Massey puts this as "the Russian Dolls issue of care and responsibility: we always begin with the proximate, home, and then move outwards. But care diminishes as we move out." 60 We might think we try to be "responsible" about our presence in a locality, even a locality that "thinks globally," as the motto goes. But the problem is much vaster. Timothy Morton writes: "the problem goes beyond how to dispose of human-sized things, like the stuff that gets flushed down a toilet. What should we do about substances on whose inside we find ourselves?"61 Critical environmental law is expected to situate itself at a distance from the hyperobject of environmental degradation and yet immerse itself in the geologic verticality of responsibility. This is the way to encourage that humans assume their responsibility in relation to their position in the planetary assemblage.

\section{Conclusion}

These theses are mere indications of how environmental law can remodel itself critically by taking into consideration some of the current important challenges. This is neither an easy, nor a unilateral task. Environmental law itself is part of an assemblage of material and immaterial bodies, and remains bound by the continuum around it. It can, however, organise itself politically and start withdrawing from the traditionally understood legal methodology. What is more, it has the responsibility to do so - more than any other branch of law, environmental law needs to reflect critically on what is expected of it and how to achieve it. And when bodies move, the assemblage often moves along and the continuum's tilt might change a little.

\footnotetext{
${ }^{60}$ D Massey, 'Geographies of Responsibility' (2004) Geografiska Annaler, Series B, Human Geography, Special Issue: The Political Challenge of Relational Space 86, 1, 5, 9.

61 Morton, supra n. 32, at 140.
} 
This is particularly hard in view of law's temporality. Rather unsurprisingly, the law has been lagging behind in terms of riding the Anthropocene wagon. This is partly because the law is always characterised by a slower, more ponderous temporality, typically operating later than politics and certainly much later than most humanities and social sciences. The reasons for this are multiple, but perhaps the most obvious one is the fact that law often operates as the final arbiter on events in which several other institutions have already been involved, such as politics, media, science and so on. Things end up in law, and for that reason, law carries the weight of confirming societal expectations. These expectations refer to the assumption that the circumstances will carry on being the way they have been so far, and that they can be relied upon not to change arbitrarily. ${ }^{62}$ This rather conservative aspect of the law is coupled to a more proactive and future-tending aspect, and the second main reason for which law is characterised by a slower temporality: the law is expected to bind the future. Every act and decision (if one wishes to look at the law narrowly), every legal spatialisation and expansion (geopolitical law), every legal gesture and movement (embodied law), and indeed every piece of legal research, bears the responsibility of capturing the future. This is simply because every piece of the legal system, to a smaller or greater extent, at the same time constructs the law and binds social expectations on how the law will be in the future.

If the above is true, then the responsibility that rests with critical environmental law is immense. As a body, it must both satisfy conservative expectations of repetition of social structures, and arrest the future in a radically open way. The methodological

62 Luhmann, supra, n. 6 
consequence of this is a researcher straddling both immersion and withdrawal, human and not human, text and matter, body and environment, perpetuation of past structures and opening of novel ones. This is a schizophrenic position, and perhaps less appealing than more standard methodologies. What we are asking here is nothing short of an other environmental law, reflective yet proactive. This can only happen through a thorough overhaul of its methodological armour. What I have suggested here is a move towards an ontological, material, mineral and situated environmental law - which also means, necessarily, an ontologically-aware, materially embedded researcher, in touch with her mineral temporality and immediate spatiality. It requires in other words, an honest facing-up by the researcher of the object in hand as a continuum with herself that cannot be ruptured through facile epistemological constructs of humans $v$ nonhumans $v$ inhumans.

This is demanding task that clearly surpasses the traditional boundaries of environmental law. But at the same time, it is not exactly a choice. We are part of an inexorable movement towards a vastly more complex, rapid and mediated planetary evolution, and we can ignore neither our historical responsibility nor our unique perhaps ability to build a better future.

\section{Bibliography}

Adelman, S, 'Climate justice, loss and damage and compensation for small island developing states' (2016) Journal of Human Rights and the Environment, 7, 1, 32 
Barad, K, Meeting the Universe Halfway: Quantum Physics and the Entanglement of Matter and Meaning (Durham, Duke University Press, 2006)

Barnett, C, P Cloke, N Clarke and A Malpass, Globalizing Responsibility: The Political Rationalities of Ethical Consumption (London, Blackwell, 2011

Baxi, U, 'Towards a climate change justice theory?' (2016) 7 Journal of Human Rights and the Environment, 7, 10

Bennett, J, Vibrant Matter: A Political Ecology of Things (Durham, Duke University Press, 2010)

Blackman, L, Immaterial Bodies (London, Sage, 2012).

Blühdorn, I, Post-ecologist Politics (London, Routledge, 2000)

Brasier, R 'Concepts and Objects' in L Bryant, N Srnicek and G Harman (eds) The Speculative Turn: Continental Materialism and Realism (re.press, 2011).

Brennan, T, The Transmission of Affect (Ithaca and London, Cornell University Press, 2004).

Capra, F, and U Mattei, The Ecology of Law: Toward a Legal System in Tune with Nature and Community (Berrett-Koehler, 2015)

Chakrabarty, D, 'The Climate of history: Four theses' (2009) 35 Critical Inquiry, 197

Colebrook,C, Death of the PostHuman: Essays on Extinction, Vol. 1 (Ann Arbor, Open Humanities Press, 2014) 
Crutzen, P J, and E Stoermer, 'The Anthropocene' (2000) 41 IGBP Newsletter 17

Deleuze, G, Cinema 1: The Movement-Image (London, Athlone Press, 1986)

Deleuze, G, Spinoza: Practical Philosophy, trans. R Hurley (San Francisco, City Light Books, 1988)

Deleuze, G, Cours Vincennes: Sur Spinoza, 17.02.1981 in L Lambert, The Funambulist Pamphlets 01: Spinoza (New York, Punctum Books, 2013)

Deleuze, G, and F Guattari, A Thousand Plateaus: Capitalism and Schizophrenia, trans. B Massumi (London, Athlone Press, 1988)

Deleuze, G, and F Guattari, What is Philosophy?, trans. H Tomlinson and G Burchell (New York, Columbia University Press, 1994)

Fisher, E, 'Environmental Law as 'Hot' Law' (2013) Journal of Environmental Law 25, 3, 347

Gatens, M, 'Through a Spinozist Lens: Ethology, Difference, Power', in P Patton (ed.), Deleuze: A Critical Reader (Oxford, Blackwell, 1996)

Gonzalez, C, 'Bridging the North-South Divide: International Environmental Law in the Anthropocene' (2015) 32 Pace Environmental Law (PELR) Review, 407

Grear, A, 'Challenging corporate 'humanity': legal disembodiment, embodiment and human rights' (2007) Human Rights Law Review 7, 3, 511 
Grear, 'Deconstructing Anthropos: A Critical Legal Reflection on "Anthropocentric" Law and Anthropocene "Humanity"' (2015) Law and Critique 26, 3, 225

Grear, A, 'Anthropocene "Time"?'-A reflection on temporalities in the 'New Age of the Human'

Haraway, D, 'Anthropocene, Capitalocene, Chthulucene: Staying with the Trouble', lecture at University of California, Santa Cruz, on $5^{\text {th }}$ September 2014, available at https://vimeo.com/97663518

Houston, D (2013) 'Crisis Is Where We Live: Environmental Justice for the Anthropocene', Globalizations, 10, 3, 439

Humphreys, S and Y Otomo, 'Theorising International Environmental Law' in F Hoffmann and A Orford (eds) The Oxford Handbook of International Legal Theory (Oxford, Oxford UP, 2014).

Kirksey, 'Multispecies Families, Capitalism, and the Law' in I Braverman (ed.), Lively Legalities (London, Routledge, 2016)

Latour, B, Facing Gaia: Six lectures on the political theology of nature (the Gifford Lectures on Natural Religion Edinburgh, 18th-28th of February 2013) 77, www.macaulay.cuny.edu/eportfolios/LATOUR-GIFFORD-SIX-LECTURES

Luhmann, N, Law as a Social System, trans. K Ziegert (Oxford, Oxford University Press, 2004)

Lorrimer, J, 'Multinatural geographies for the Anthropocene' (2012) Progress in Human Geography, 36, 5, 59 
Massey, D 'Geographies of Responsibility' (2004) Geografiska Annaler, Series B, Human Geography, Special Issue: The Political Challenge of Relational Space 86, 1, 5, 9

Merchant, C, The Death of Nature: Women, Ecology and the Scientific Revolution (Wildwood House 1980)

Morton, T, The Ecological Thought (Harvard University Press 2010)

Morton, T, Hyperobjects: Philosophy and Ecology after the End of the World (Minneapolis, University of Minnesota Press, 2013).

Neimanis, A, C Åsberg and J Hedréncall, 'Four Problems, Four Directions For Environmental Humanities: Toward Critical Posthumanities For the Anthropocene', Ethics \& Environment, $2015++$

Philippopoulos-Mihalopoulos, A, 'Towards a Critical Environmental Law', in A PhilippopoulosMihalopoulos (ed), Law and Ecology: New Environmental Foundations (London, Routledge, 2011).

Philippopoulos-Mihalopoulos, A, Spatial Justice: Lawscape Body Atmosphere (London, Routledge, 2015)

Philippopoulos-Mihalopoulos, A 'Epistemologies of Doubt', in A Grear and L Kotzé (eds), Research Handbook On Human Rights And The Environment (Cheltenham, Edward Elgar, 2015) 
Philippopoulos-Mihalopoulos, A, 'Actors or spectators? Vulnerability and critical environmental law', in A Grear and E Grant (eds), Thought, Law, Rights and Action in the Age of Environmental Crisis (Cheltenham, Edward Elgar, 2015).

Philippopoulos-Mihalopoulos, A 'Lively Agency: Life and Law in the Anthropocene', in I Braverman, Lively Legalities (London, Routledge, 2016)

Robinson, N, 'Fundamental Principles of Law for the Anthropocene?' (2014) Environmental Policy and Law, 44, 1-2, 13

Rowan, R, 'IV Notes on politics after the Anthropocene' (2014) in E Johnson et al. (eds) Special Issue 'After the Anthropocene: Politics and geographic inquiry for a new epoch' Progress in Human Geography, 9

Sarat, A “ "... The Law is All Over”: Power, Resistance and the Legal Consciousness of the Welfare Poor' (1990) Yale Journal of Law and Humanities, 2, 2, 343

Swyngedouw, E, 'The non-political politics of climate change' (2011) Acme 12, 1, 1

Turpin, E, 'Who Does the Earth Think It Is, Now?', in E Turpin (ed), Architecture in the Anthropocene: Encounters Among Design, Deep Time, Science and Philosophy (Open Humanities Press, 2013)

Yussof, K, 'Geologic subjects: nonhuman origins, geomorphic aesthetics and the art of becoming inhuman' (2015) Cultural Geographies, 22, 3, 383

Yussof, K, 'Anthropogenesis: Origins and Endings in the Anthropocene' (2016) Theory, Culture \& Society, 33, 2 
Warf, B, and S Arias (eds.), The Spatial Turn: Interdisciplinary Perspectives (New York, Routledge, 2009)

Woodard, B, On an Ungrounded Earth: Towards a New Geophilosophy (Punctum Books, 2013)

Zalasiewicz, J, et al., 'Stratigraphy of the Anthropocene' (2011) Philosophical Transactions of the Royal Society A, 369, 1036, 